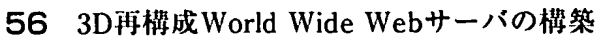
山口大学医学部付属病院·放射線部 上田克彦，真田泰三，松永尚文 山口大学大学院理工学研究科 兼清 博. 佐々木伸司. 檑 理恵 木戸尚治

山口大学医学部医学科構造制御病態学講座 松本常男

【目的】近年MDCTの登場によりCT画像はaxial画像だけでなくMPR画 像などの3D画像も診断に大きく寄与している. 現在3D画像は一般的 にCTコンソールまたはワークステーションで再構成され限られた方 向からの画像だけが診断医に提供されることが多い. 現在われわれ はCT・MR・核医学・血管造影用統合画像サーバシステムを運用し モニ夕診断を実施しているが，システム一部として3D画像再構成お よび元画像保存のためのサーバシステムを構筑したので報告する.

【方法】放射線部画像LAN上にWorld Wide Webサーバを用いた3D再 構成サーバシステムを構築し，撮影画像の読込み，表示を一連の作 業で動作させる設計とした．また，3Dの再構成の作業を連携できる インターフェイスを実装するため，Webブラウザ上で動作するJava Appletを利用し, すべての読影端末でCT画像のMPR再構成プログラ ムをWebブラウザ上で実現できるように設計した。

【結果】現在MDCTから1シリーズ250枚から400枚程度の元画像を3D サーバに保存し，診断医が必要とするときに読影端末からWebブラ ウザ上で元画像およびMPR再構成プログラムを転送LMPR像を診断 に試験的に用いている。

【考察】専用ワークステーションを用いることなく，すべての読影端 末上で診断医がMPR画像を作成することにより効率の良い検査が実 施できる。また，通常の診断用画像システムと切り離すことでLAN 上の運用速度に影響を与えることが少ない，また，研究目的に元画 像を保存することも可能で長期保存の必要性のないデー夕は削除す ることが可能. 現在は3D再構成プログラムだけが搭载されている が, 将来診断支援システムなどの機能の拡張がサーバのみのバー ジョンアップで可能である.

57 ギガビットネットワークを活用した $3 \mathrm{D}$ 作成サーバのパフォー マンステスト

名古屋大学医学部保健学科 津坂昌利

藤田保健衛生大学総合医科学研究所 長嶋宏和

岐皁大学医学研究科再生医科学専攻 原 武史

名古屋大学大学院医学系研究科修士課程 飯田炗子, 野上真子

【目的】ギガビットネットワークを活用した3D作成サーバのネット ワーク・パフォーマンステストを行い，クライアントパソコン接続 数と処理能力の関係を評価する.

【方法】ネットワークアナライザSnifferを用いて，ネットワークを流 れるパケットを解析し, クライアントパソコンの接続台数による負 荷の状況を測定し評価した。

【結果】AquariousNET(テラリコン社製)3D作成サーバは，マルチスラ イスCTなどの画像をDICOM形式で転送し，3D画像を作成できるセ ンターサーバ式の装置である.クライアントには市販されている Windowsマシンを使用でき，専用ソフトをインストールすることに よって，ネットワーク経由で3D画像の作成，表示ができる．当初 100Mbpsのネットワークを用いてパフォーマンスをチェックした が, クライアントパソコン 1 台あたり, シネ表示モードで約25Mbps の帯域を使用し，3，4台同時使用で100Mbpsのネットワーク帯域を 使い尽くすことが分かった。 今回，サーバに1Gbpsのネットワーク カードを挿入し，ギガビットネットワークを用いてネットワークの パフォーマンスをチェックしたので総合的な性能について報告す る. ギガビットネットワークを用いることによって, ネットワーク のパフォーマンスは飛躍的に向上し, クライアントパソコン10台接 続試験においても，有用な結果が得られた。
58 RISにおけるトラフル対策 金沢医科大学病院·中央放射線部川嶋政広，香坂 誠，清水和弥 飛田 明

【目的】当病院では, 院内オータエントリーシステムおよび電子カル テシステムに連携して画像・画像情報・読影レポート・検查実施情 報・医事会計情報・物流情報・予約情報などをRISにて管理してい る．突然のハード障害や停電・瞬電などによるトラブル対策につい てハード・ソフト両面について報告する。

【方法】(1)フイルサーバのデータに関してはファイル構造をミラー 化し，さらにバックアップ処理を行う。医事会計情報・物流情報・ 予約情報などの他部門との送信に関してはCPUを二重化しハード故 障時に 1 分弱で切り替えを可能とした。 (2) 院内画像提供システム では各モダリティごとのファイルサーバの状態を把握するため監視 画面を作成し一括監視を行う. (3)オーダエントリーシステムが停止 した場合，伝票にても運用可能とした。(4)設定保存期間が過ぎた データの削除処理を自動化. (5) 飛雷による停電・瞬電やコンセント からの逆流によるトラブル対策として, 無停電装置の設置の徹底と 逆流の恐れのあるコンセントにはOAプロテクタを設置.

【結果・考察】(1)CPUの二重化によりハード障害時，業務に支障を来 さない. (2)各モダリティごと,リアルタイムの状態把握が可能とな ク，トラブルに対して迅速に対応できる. (3)トラブル発生時に伝票 運用に切り替えることにより患者への負担軽減となる. (4)ファイル の満杯によるシステム停止の防止. (5)停電時や瞬電時の装置へのリ スクを最小限にした。 トラブル対策は他部門に対して情報提供や業 務を円滑に稼動するためには重要と思われる。

\section{9 位置情報付き画像診断レポートシステムの權筑} 大阪大学大学院医学系研究科保健学専攻 周藤俊治. 芦田信之 医誠会病院ソフィア健康增進センター 赤木信裕，稲本一夫 【目的】さまざまなモダリティを通じて得られる放射線画像情報は濃 淡で表現される情報であり数値データのように一義的な判断が行え ないため専門医による読影が必要である、診断レポートと画像は互 いに情報を補間しているものであるが，診断レポートにおいて病変 部位が画像のどの位置を示しているのか表現することが困難であ り，一般医や患者へ情報が十分に伝わりにくい，そこで位置情報に ついてコンピュータ上で時間や空間を越えてお互いのコミュニケー ションを再現できる環境を構築した。

【方法】本システムの設計にあたり multi-modal communicationの概念を 取り入れ，診断レポートに㫪かれた病変部位をインタラクティブに 画像上でポイントする仕様とした。情報の発信者である専門医が画 像上で病変部位をマウスでクリックすることでDynamic HTMLコー ドを自動生成する専用ソフトを開発し，情報の受信者である一般 医・患者は出力されたコードをWebブラウザにて診断レポートと画 像ならびに病変部位を動的に閲覧できるシステムとした。なお，閲 覧についてはネットワーク上でも，オフラインでも可能であるが今 回は医誠会病院ソフィア健康增進センターにて健康診断の結果を CD-ROMで配布するシステム(電脳画像盤®)に組み込み受診者への 情報提供を行った.

【結果および考察】本システムを導入する以前の診断レポートと比べ 飛躍的に画像情報について専門医と一般医・患者間の情報伝達が円 滑になったとの評価を得た。本システムによる分かりやすい情報の 提供はインフォームドコンセントや，七カンドオピニオンの点から も有意㼁であると考えられる。 